\title{
LEVELS OF MIR-374 INCREASE IN BEWO B30 CELLS EXPOSED TO HYPOXIA
}

Knyazev EN $\mathrm{N}^{1,2,3} \otimes$, Paul SYu2,4

${ }^{1}$ Shemyakin-Ovchinnikov Institute of Bioorganic Chemistry of the Russian Academy of Sciences, Moscow

${ }^{2}$ National Research University Higher School of Economics, Moscow

${ }^{3}$ Translational Technology Center, Moscow

${ }^{4}$ Troitsk Research and Development Center, Moscow

In humans, trophoblast hypoxia during placental development can be a cause of serious pregnancy complications, such as preeclampsia and fetal growth restriction. The pathogenesis of these conditions is not fully clear and may be associated with changed expression of some genes and regulatory molecules, including miRNA, in trophoblast cells. The aim of this study was to analyze miRNA profiles and measure the expression of their target genes in a model of trophoblast hypoxia. Human choriocarcinoma BeWo b30 cells were used as a trophoblast model. Hypoxia was induced by cobalt chloride $\left(\mathrm{CoCl}_{2}\right)$ and an oxyquinoline derivative. MRNA and miRNA expression profiles were evaluated by means of next generation sequencing (NGS); the expression of individual genes was analyzed by PCR. We studied the secondary structure of mRNAs of target genes for those miRNAs whose expression had changed significantly and analyzed potential competition between these miRNAs for the binding site. The observed changes in the expression of the key genes involved in the response to hypoxia confirmed the feasibility of using $\mathrm{CoCl}_{2}$ and the oxyquinoline derivative as hypoxia inducers. The analysis revealed an increase in miR-374 levels following the activation of the hypoxia pathway in our trophoblast model. The changes were accompanied by a reduction in FOXM1 mRNA expression; this mRNA is a target for hsa-miR-374a-5p and hsa-miR374b-5p, which can compete with hsa-miR-21-5p for the binding sites on FOXM1 mRNA. The involvement of FOXM1 in the regulation of the invasive cell potential suggests the role of miR-374 and FOXM1 in the pathogenesis of disrupted trophoblast invasion during placental development as predisposing for fetal growth restriction and preeclampsia.

Keywords: placenta, choriocarcinoma, BeWo, hypoxia, cobalt, oxyquinoline, FOXM1, microRNA, miR-374a-5p, miR-374b-5p

Funding: This work was supported by the Russian Science Foundation (Grant № 19-74-00145).

Author contribution: Knyazev EN analyzed the literature, planned the study, collected and interpreted the obtained data, and wrote the manuscript; Paul SYu analyzed the literature and the obtained data and wrote the manuscript.

Compliance with ethical standards: the study complied with the Declaration of Helsinki.

$\triangle$ Correspondence should be addressed: Evgeny N. Knyazev

Miklouho-Maclay, 16/10, Moscow, 117437; knyazevevg@gmail.com

Received: 20.04.2021 Accepted: 28.04.2021 Published online: 30.04.2021

DOI: $10.24075 / \mathrm{brsmu} .2021 .021$

\section{УРОВЕНЬ МИКРОРНК MIR-374 ПОВЫШАЕТСЯ В КЛЕТКАХ ВЕWО В30 ПРИ ГИПОКСИИ}

Е. Н. Князев ${ }^{1,2,3} \square$, С. Ю. Пауль

${ }^{1}$ Институт биоорганической химии имени М. М. Шемякина и Ю. А. Овчинникова, Москва, Россия

${ }^{2}$ Национальный исследовательский университет «Высшая школа экономики», Москва, Россия

${ }^{3}$ Центр трансляционных технологий, Москва, Россия

${ }^{4}$ Троицкий инженерный центр, Москва, Россия

Воздействие гипоксии на клетки трофобласта в процессе формирования плаценты человека может приводить к развитию ряда патологий беременности, таких как преэклампсия и задержка роста плода. Патогенез данных состояний не до конца раскрыт и может быть связан с изменением экспрессии в трофобласте ряда генов и регуляторных молекул, включая микроРНК. Целью данного исследования было изучить профили микроРНК и экспрессии соответствующих генов-мишеней в модели гипоксии трофобласта. Моделирование трофобласта проводили с использованием клеточной линии хориокарциномы человека BeWo b30. B качестве индукторов гипоксического ответа использовали хлорид кобальта (СоСl $)$ и производное оксихинолина. Анализировали уровень MPHK и микроРHK с помощью секвенирования следующего поколения (NGS) с подтверждением экспрессии отдельных генов ПЦР. Анализировали вторичную структуру мРНК гена-мишени значимо изменившихся микроРНК и возможную конкуренцию за

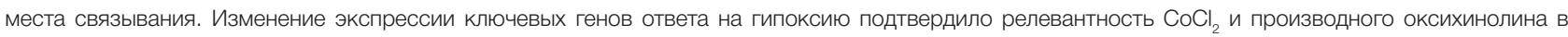
качестве индукторов гипоксии. Выявлено повышение уровня микроРНК семейства miR-374 при индукции гипоксического пути в модели тросробласта. Наблюдаемые изменения сопровождались снижением экспрессии мPHK гена FOXM1, которая служит мишенью для hsa-miR-374a-5p и hsa-miR-374b-5p. Данные микроРНК могут конкурировать за места связывания в мРHK FOXM1 c hsa-miR-21-5p. Участие гена FOХM1 в регуляции инвазивного потенциала клеток позволяет предположить роль микроРHK miR-374 и FOXM1 в патогенезе нарушения инвазии трофобласта при формировании плаценты как предпосылки к развитию задержки роста плода и преэклампсии.

Ключевые слова: плацента, хориокарцинома, BeWo, гипоксия, кобальт, оксихинолин, FOXM1, микроPHK, miR-374a-5p, miR-374b-5p

Финансирование: исследование выполнено за счет гранта Российского научного фонда (проект № 19-74-00145).

Вклад авторов: Е. Н. Князев - анализ литературы, планирование исследования, сбор и интерпретация данных, подготовка рукописи; С. Ю. Пауль анализ литературы, анализ данных, подготовка рукописи.

Соблюдение этических стандартов: работа выполнена с соблюдением этических принципов и требований Хельсинкской декларации Всемирной медицинской организации и последующих ее пересмотров.

$\triangle$ Для корреспонденции: Евгений Николаевич Князев ул. Миклухо-Маклая, д. 16/10, г. Москва, 117437; knyazevevg@gmail.com

Статья получена: 20.04.2021 Статья принята к печати: 28.04.2021 Опубликована онлайн: 30.04.2021

DOI: 10.24075/vrgmu.2021.021 
The maintenance of homeostasis during fetal development is essential for a healthy pregnancy. In pregnancy, trophoblast cells replace the endothelial lining of uterine spiral arteries, making them insensitive to systemic tone regulators and thus ensuring a constant blood flow to the placenta and the fetus. Inflammation and severe hypoxia impair trophoblast invasion [1], which is believed to be one of the major causes of preeclampsia, a severe pregnancy complication. MicroRNA (miRNA) secreted by trophoblast cells in the setting of hypoxia may be markers of impending preeclampsia and, at the same time, a pathogenic component of this condition due to their role as regulators of gene expression [2-4].

In vitro trophoblast models employ human choriocarcinoma cell lines, like BeWo b30: they are not susceptible to contact inhibition, can form confluent cell layers, have high motility [5], and therefore can be used as both villous or extravillous trophoblast models. The use of microfluidic platforms allows researchers to bring a trophoblast model closer to the actual conditions inside the organism [6, 7].

The activation of the hypoxia signaling pathway is associated with the transcription of hypoxia-inducible factor (HIF) targets. One of the classical ways to model chemical hypoxia is through exposure of the cell to cobalt (II) chloride, a compound that causes an elevation of HIF levels in the cell [8]. Derivatives of 8-oxyquinoline (OD), too, are capable of activating the hypoxia pathway by stabilizing HIF in the cell [9]. OD effects on BeWo b30 cells imitate the effects of hypoxia in the placental trophoblast [10].

The aim of this study was to analyze miRNA profiles and the expression of miRNA target genes in a model of trophoblast hypoxia.

\section{METHODS}

BeWo b30 cells were kindly provided by Prof. Dr. Christiane Albrecht (University of Bern, Switzerland) with permission from Prof. Dr. Alan Schwartz (Washington University in St. Louis, USA). The obtained cells were grown in 6-well plates, growth area $9.6 \mathrm{~cm}^{2}$ (Corning; USA) in Gibco DMEM, high glucose (Thermo Fisher Scientific; USA) supplemented with 10\% Gibco FBS One Shot (Thermo Fisher Scientific; USA), 1\% Gibco MEM NEAA (100X) and 1\% Gibco Pen Strep (100X). Upon reaching $80 \%$ confluence, the cells were transferred to a fresh medium that did not contain any chemical inducers of hypoxia or to a medium supplemented with 5 HM OD 4896-3212 (ChemRar High-Tech Center; Russia) or with $300 \mu \mathrm{M}$ cobalt (II) chloride (Sigma-Aldrich; USA). After $24 \mathrm{~h}$, the cells were lysed in a Qiazol Lysis Reagent (Qiagen; Germany), and RNA was extracted by means of phenol-chloroform extraction [11] using a miRNeasy Mini Kit (Qiagen; Germany). RNA concentrations were measured with a NanoDrop 1000 spectrophotometer (Thermo Fisher Scientific; USA). RNA quality control was performed in an Experion automated electrophoresis system (Bio-Rad; USA). RNA Quality Indicator (RQI) was at least 9 for all the trialed samples.

Libraries for next generation sequencing (NGS) were prepared using an NEBNext Multiplex Small RNA Library Prep Kit for Illumina (New England Biolabs; USA) and Illumina Stranded mRNA Library Prep Kit (Illumina; USA). The libraries were then sequenced in a NextSeq 500 System (Illumina; USA).

To analyze the expression of individual genes, $500 \mathrm{ng}$ total RNA was reverse-transcribed using an M-MLV RT Kit (Evrogen; Russia). The obtained DNA was amplified by real-time PCR using qPCRmix-HS SYBR reagents (Evrogen; Russia). Differences in mRNA and miRNA expression between BeWo b30 cultures exposed and unexposed to hypoxia inducers were analyzed using Student's $t$-test and the Benjamini-Hochberg procedure for multiple comparisons to control the False Discovery Rate (FDR). Differential expression analysis was conducted using DESeq2 v1.28.1 [12] Differences in the expression of highly represented miRNA and mRNA were considered significant at FDR- $p<0.05$ and log2 fold change not less than 0.4 [13].

\section{RESULTS}

The analysis of publications investigating the effects of hypoxia on the transcriptome of various cells allowed to identify a number of key genes involved in the cell response to hypoxia [14]. The expression of these genes in BeWo b30 cells exposed to OD and $\mathrm{CoCl}_{2}$ was estimated from NGS data (Table 1). The expression of all genes listed in Table 1 changed significantly $(p<0.05)$, except for the genes CDKN1A and ENO1 in the cells exposed to OD and the genes SLC2A1 and TMEM45A in the cells exposed to $\mathrm{CoCl}_{2}$. Interestingly, the expression of the EPO gene, which encodes erythropoietin, decreased in BeWo b30 cells exposed to cobalt, whereas under true hypoxia with low oxygen levels its expression increases [14], just like in BeWo b30 cells exposed to OD.

To verify the results of sequencing and confirm the activation of key hypoxia-responsive genes, the expression of BNIP3, SLC2A3, PDK1 and VEGFA in BeWo b30 cells was evaluated by PCR. ACTB and GUSB were used as reference genes. PCR confirmed that the expression of the listed genes had been activated (Table 2).

Among highly expressed miRNAs accounting for over 95\% of all BeWo b30 miRNAs, those miRNAs were identified whose level had changed significantly in the setting of chemically induced hypoxia. Those included 7 miRNAs expressed in BeWo b30 cells exposed to OD (Table 3) and 16 miRNAs expressed in BeWo b30 cells exposed to $\mathrm{CoCl}_{2}$ (Table 4); only 2 miRNAs (hsa-miR-374a-5p and hsa-miR-374b-5p) occurred in both lists.

We analyzed the expression of hsa-miR-374a-5p and hsamiR-374b-5p targets in BeWo b30 cells exposed to OD and $\mathrm{CoCl}_{2}$. An earlier study reports that hsa-miR-374b-5p can regulate FOXM1 expression in SiHa cervical cancer cells [15]. In our study, FOXM1 expression in BeWo b30 cells decreased significantly after exposure to OD and $\mathrm{CoCl}_{2}$ (1.7 and 2.6-fold, respectively). Previously, it was shown that hsa-miR-21-5p can caused a decline in FOXM1 expression [16]; so, we analyzed the seed regions of hsa-miR-21-5p, hsa-miR-374a-5p and hsa-miR-374b-5p, to reveal that each of these 3 miRNAs has only one binding site in the 3'-untranslated FOXM1 mRNA region (see the Figure).

\section{DISCUSSION}

Cell responses to hypoxia may vary, which shows in the activation of different genes and in the varying degrees of such activation. An earlier literature analysis identified a number of key genes activated in all cells exposed to hypoxia [14]. The expression of those genes was also elevated in our BeWo b30 cells exposed to OD and $\mathrm{CoCl}_{2}$, suggesting the activation of the HIF pathway. There are reports that BeWo cells exposed to $\mathrm{CoCl}_{2}$ overexpress glucose transporter 1 (GLUT1) encoded by the SLC2A1 gene [17-19]. These reports are consistent with our findings. Interestingly, the expression of the EPO gene, which encodes erythropoietin, declined in BeWo b30 cells exposed to $\mathrm{CoCl}_{2}$, whereas true hypoxia with low oxygen levels causes an increase in EPO expression [14], just like in 
Table 1. Expression of key genes involved in response to hypoxia in BeWo b30 cells (based on sequencing data)

\begin{tabular}{|l|c|c|}
\hline \multirow{2}{*}{ Gene } & \multicolumn{2}{|c|}{$\log _{2}$ fold change } \\
\cline { 2 - 3 } & Exposure to OD & Exposure to $\mathrm{CoCl}_{2}$ \\
\hline DDIT4 & 3.5 & 3.6 \\
\hline KDM3A & 1.8 & 3.6 \\
\hline BNIP3 & 2.3 & 3.3 \\
\hline NDRG1 & 3.4 & 2.8 \\
\hline SLC2A3 & 3.1 & 2.6 \\
\hline BHLHE40 & 2.8 & 2.5 \\
\hline P4HA1 & 2.9 & 2.3 \\
\hline PDK1 & 1.7 & 2 \\
\hline ANKRD37 & 3.2 & 1.9 \\
\hline VEGFA & 1.6 & 1.9 \\
\hline ERO1A & 1.7 & 1.8 \\
\hline ALDOC & 4.4 & 1.3 \\
\hline CDKN1A & $0.6^{*}$ & 1.1 \\
\hline STC2 & 1.3 & 1 \\
\hline ENO1 & $0.6^{*}$ & $0.7^{*}$ \\
\hline SLC2A1 & 1.4 & $0.1^{*}$ \\
\hline TMEM45A & 2 & -1.5 \\
\hline EPO & 1.4 & \\
\hline
\end{tabular}

Note: * - designates FDR- $p>0.05$; for other genes, FDR- $p<0,05$.

BeWo b30 cells exposed to OD. It was shown previously that $\mathrm{HIF}$ can directly increase EPO expression in BeWo cells [20]. In another study, the level of EPO expression in BeWo cells was undetectable, which did not allow the researchers to assess how $\mathrm{CoCl}_{2}$ and hypoxia affected its expression [21]. Cobalt is known to stimulate erythropoietin expression in the kidneys [22]. EPO expression is controlled by HIF-2 $\alpha$, and though cobalt generally induces both $\mathrm{HIF}-1 \alpha$, and $\mathrm{HIF}-2 \alpha$, it did not affect EPO expression in liver cancer cell lines Huh7 and HepG2 [23]. Perhaps, the expression of this gene may be dependent not only on the activation of the HIF signaling pathway but also on other tissue-specific factors.

Exposure of trophoblast cells to hypoxia can induce the release of certain molecules, including hypoxia-associated miRNA [24]. MiRNA released by the cell can affect the

neighboring cells; shifts in miRNA expression may determine the scope of miRNA effects. However, microRNA concentrations in the producing cell have to be sufficiently for such effects to occur. Therefore, we selected $10 \%$ of miRNAs that were present in the highest concentrations in the BeWo b30 culture and then identified those whose expression had changed significantly following BeWo b30 exposure to OD or $\mathrm{CoCl}_{2}$. Interestingly, of all miRNAs whose expression had significantly changed after exposure to OD or $\mathrm{CoCl}_{2}$ ( 7 and 16 miRNAs respectively) only 2 (hsa-miR-374a-5p and hsa-miR-374b$5 p)$ responded with overexpression to both hypoxia inducers. These 2 miRNAs are encoded in the X-chromosome in the introns of the FTX gene that codes for the long non-coding RNA participating in the inactivation of the $X$-chromosome. The miR-374 family members participate in the regulation of cell

Table 2. Expression of key genes involved in response to hypoxia in BeWo b30 cells (based on PCR data)

\begin{tabular}{|l|c|c|}
\hline \multirow{2}{*}{ Gene } & \multicolumn{2}{|c|}{ Linear fold change* } \\
\cline { 2 - 3 } & Exposure to OD & \multicolumn{2}{|c}{${\text { Exposure to } \mathrm{CoCl}_{2}}^{*}$} \\
\hline BNIP3 & 3.7 & 3.6 \\
\hline SLC2A3 & 2.2 & 2.4 \\
\hline PDK1 & 1.7 & 3.1 \\
\hline VEGFA & 1.6 & \\
\hline
\end{tabular}

Note: * FDR- $p<0,05$.

Table 3. MiRNA with significantly changed expression after exposure to OD

\begin{tabular}{|l|c|c|}
\hline \multicolumn{1}{|c|}{ miRNA } & $\log _{2}$ fold change & FDR- $p$ \\
\hline hsa-miR-96-5p & $\downarrow 0.5$ & $1.8 \times 10^{-3}$ \\
\hline hsa-miR-21-5p & $\uparrow 0.4$ & $2.7 \times 10^{-2}$ \\
\hline hsa-miR-429 & $\uparrow 0.5$ & $4.2 \times 10^{-4}$ \\
\hline hsa-miR-374b-5p & $\uparrow 0.5$ & $6.6 \times 10^{-3}$ \\
\hline hsa-miR-374a-5p & $\uparrow 0.5$ & $1.4 \times 10^{-3}$ \\
\hline hsa-miR-26b-5p & $\uparrow 0.6$ & $8.0 \times 10^{-8}$ \\
\hline hsa-miR-181a-2-3p & $\uparrow 0.7$ & $3.8 \times 10^{-7}$ \\
\hline
\end{tabular}


Table 4. MiRNA with significantly changed expression after exposure to $\mathrm{CoCl}_{2}$

\begin{tabular}{|c|c|c|}
\hline miRNA & $\log _{2}$ fold change & FDR- $p$ \\
\hline hsa-miR-1260b & $\downarrow 0.7$ & $9.8 \times 10^{-9}$ \\
\hline hsa-miR-4521 & $\downarrow 0.7$ & $1.6 \times 10^{-11}$ \\
\hline hsa-miR-148a-3p & $\downarrow 0.7$ & $8.5 \times 10^{-8}$ \\
\hline hsa-miR-425-5p & $\downarrow 0.5$ & $4.1 \times 10^{-12}$ \\
\hline hsa-miR-378i & $\downarrow 0.5$ & $6.6 \times 10^{-10}$ \\
\hline hsa-miR-32-5p & $\downarrow 0.4$ & $2.5 \times 10^{-4}$ \\
\hline hsa-miR-151a-3p & $\downarrow 0.4$ & $2.1 \times 10^{-5}$ \\
\hline hsa-miR-200a-3p & $\uparrow 0.4$ & $2.5 \times 10^{-5}$ \\
\hline hsa-miR-126-3p & $\uparrow 0.4$ & $4.0 \times 10^{-7}$ \\
\hline hsa-miR-484 & $\uparrow 0.4$ & $9.5 \times 10^{-8}$ \\
\hline hsa-miR-181a-5p & $\uparrow 0.5$ & $5.2 \times 10^{-11}$ \\
\hline hsa-miR-25-3p & $\uparrow 0.5$ & $7.8 \times 10^{-11}$ \\
\hline hsa-miR-27a-3p & $\uparrow 0.5$ & $1.2 \times 10^{-12}$ \\
\hline hsa-miR-320a-3p & $\uparrow 0.5$ & $7.0 \times 10^{-11}$ \\
\hline hsa-miR-374a-5p & $\uparrow 0.6$ & $6.1 \times 10^{-6}$ \\
\hline hsa-miR-374b-5p & $\uparrow 0.6$ & $5.1 \times 10^{-7}$ \\
\hline
\end{tabular}

proliferation and differentiation, growth and carcinogenesis [25]. Hsa-miR-374a-5p and hsa-miR-374b-5p have a very similar sequence; the seed-regions of these molecules are the same, suggesting that they target the same genes. It was reported that hsa-miR-374a-5p concentrations were elevated in the blood of women who delivered prematurely [26] or gave birth to babies with small gestational weight [27]; this might indicate a potential association between hypoxia and placental pathology. Under hypoxic conditions, villous trophoblast changes its metabolism from aerobic to anaerobic; this reduces oxygen consumption but increases the need for glucose. As a result, the fetus receives more oxygen but less nutrition, which might lead to intrauterine growth restriction and premature delivery [28]. A similar effect was observed in BeWo b30 cells exposed to another OD [10].

FOXM1 was identified as an hsa-miR-374a-5p and hsa-miR$374 \mathrm{~b}-5 \mathrm{p}$ gene target; this gene encodes a transcriptional factor. The levels of its mRNA in BeWo b30 cells declined following exposure to $\mathrm{OD}$ and $\mathrm{CoCl}_{2}$. An earlier study demonstrated that hsa-miR-21-5p was capable of reducing FOXM1 expression

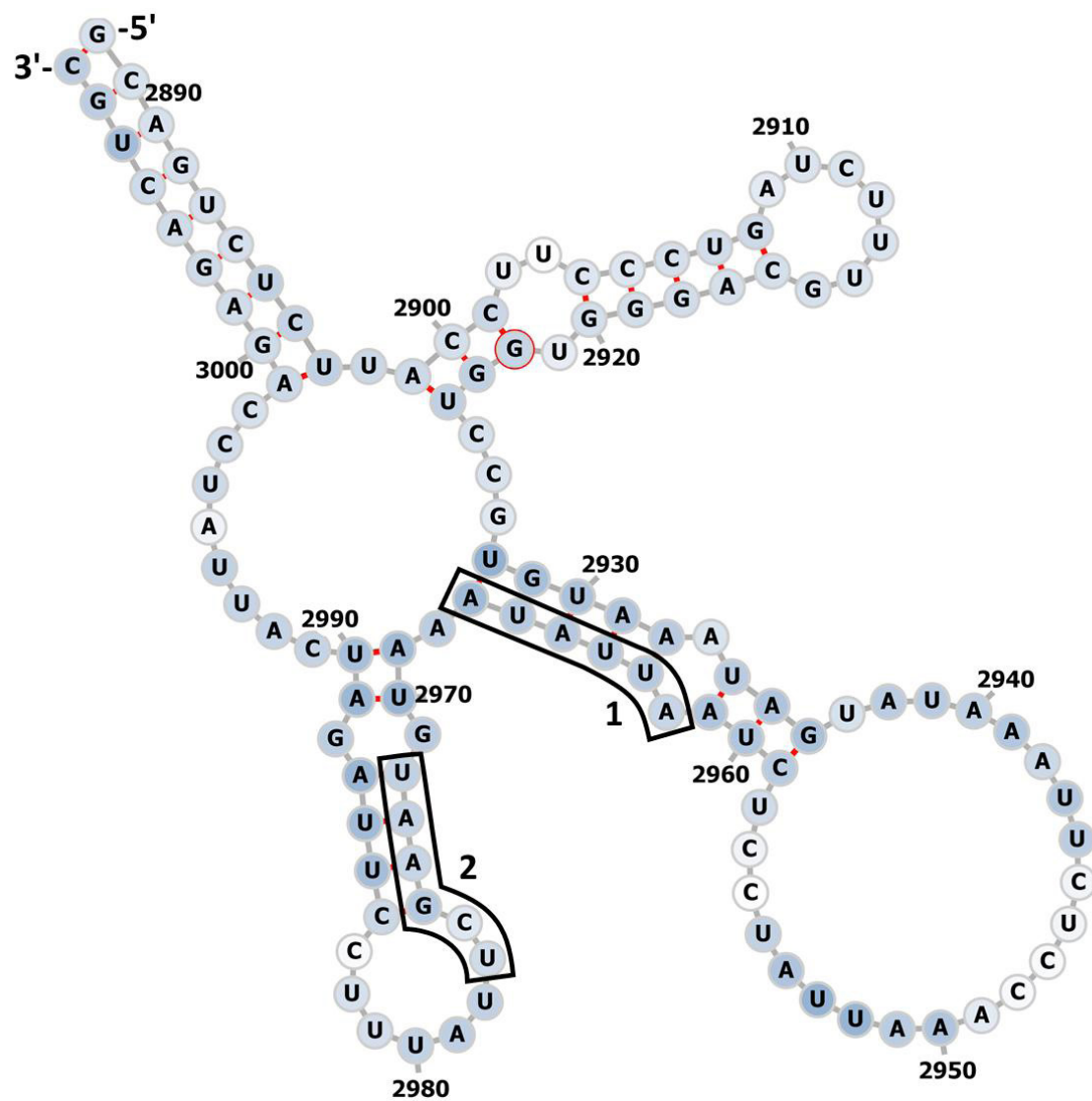

Fig. Positions of microRNA binding sites on a fragment of a 3'-untranslated region of FOXM1 mRNA (transcription variant 2). Nucleotide numbers are represented by 4 -digit numbers. 1 - binding sites for hsa-miR-374a-5p and hsa-miR-374b-5p; 2 - a binding site for hsa-miR-21-5p 
and proliferation of HTR8/SVneo choriocarcinoma cells; in the setting of preeclampsia, hsa-miR-21-5p levels were increased and the expression of FOXM1 was decreased in the placenta [16]. These reports are in good agreement with our findings. At the same time, a significant elevation of hsamiR-21-5p concentrations in BeWo b30 cells was observed only after exposure to OD, as opposed to $\mathrm{CoCl}_{2}$, suggesting the involvement of hsa-miR-374a-5p and hsa-miR-374b-5p in the regulation of FOXM1 expression in our trophoblast model. According to the spatial principle, the proximity of binding sites implies competition between hsa-miR-21-5p and hsa-miR$374 a-5 p / h s a-m i R-374 b-5 p$, because in order for the complex of argonaute proteins with these miRNAs to interact with FOXM1 mRNA, a significant steric strain is needed in the target mRNA sequence (see the Figure).

Impaired trophoblast invasion of the uterine wall and spiral arteries in the setting of preeclampsia might be explained by the reduced expression of FOXM1 governed by hsa-miR$374 b-5 p$, as was previously demonstrated for SiHa cervical cancer cells [15]. At < 3\% oxygen level simulating physiological hypoxia, FOXM1 expression in JEG-3 choriocarcinoma cells was initially high. But as the level of oxygen was falling, so was the expression of the gene. FOXM1 knockdown suppressed JEG-3 cell migration, and the culture medium in which the cells had been grown inhibited angiogenesis in the culture of endothelial cells (HUVEC) [29].

\section{CONCLUSIONS}

Our study demonstrates that exposure of BeWo b30 cells to oxyquinoline derivatives and cobalt (II) chloride may be used as a trophoblast hypoxia model. This was confirmed by the activation of key hypoxia-responsive genes. At the same time, the response of BeWo b30 cells to hypoxia manifesting in the changed miRNA expression varied significantly depending on the compound used to induce hypoxia. Both cobalt and the oxyquinoline derivative caused an increase in the expression of miR-374, suggesting its participation in response to hypoxia. The reduced expression of FOXM1, the gene target for the miR-374 family, suggests the role of miR-374 and FOXM1 in the pathogenesis of impaired trophoblast invasion during placental development as a prerequisite for intrauterine growth restriction and preeclampsia.

\section{References}

1. Yang C, Song G, Lim W. Effects of extracellular vesicles on placentation and pregnancy disorders. Reproduction. 2019; 158 (5): R189-96. DOI: 10.1530/REP-19-0147.

2. Li H, Ouyang Y, Sadovsky E, Parks WT, Chu T, Sadovsky Y. Unique microRNA Signals in Plasma Exosomes from Pregnancies Complicated by Preeclampsia. Hypertension. 2020; 75 (3): $762-$ 71. DOI: 10.1161/HYPERTENSIONAHA.119.14081.

3. Makarova J, Turchinovich A, Shkurnikov M, Tonevitsky A. Extracellular miRNAs and Cell-Cell Communication: Problems and Prospects Trends Biochem Sci. 2021. DOI: 10.1016/j.tibs.2021.01.007.

4. Makarova JA, Maltseva DV, Galatenko W, Abbasi A, Maximenko DG, Grigoriev Al, et al. Exercise immunology meets MiRNAs. Exerc Immunol Rev. 2014; 20: 135-64.

5. Nikulin SV, Knyazev EN, Gerasimenko TN, Shilin SA, Gazizov IN, Zakharova GS, et al. Impedance Spectroscopy and Transcriptome Analysis of Choriocarcinoma BeWo b30 as a Model of Human Placenta. Mol Biol. 2019; 53 (3): 411-8. DOI: 10.1134/ S0026893319030130

6. Nikulin SV, Knyazev EN, Gerasimenko TN, Shilin SA, Gazizov IN, Zakharova GS, et al. Non-Invasive Evaluation of Extracellular Matrix Formation in the Intestinal Epithelium. Bull Exp Biol Med. 2018; 166 (1): 35-8. DOI: 10.1007/s10517-018-4283-7.

7. Samatov TR, Shkurnikov MU, Tonevitskaya SA, Tonevitsky AG Modelling the metastatic cascade by in vitro microfluidic platforms. Prog Histochem Cytochem. 2015; 49 (4): 21-9. DOI: 10.1016/j. proghi.2015.01.001.

8. Muñoz-Sánchez J, Chánez-Cárdenas ME. The use of cobalt chloride as a chemical hypoxia model. J Appl Toxicol. 2019; 39 (4): 556-70. DOI: 10.1002/jat.3749.

9. Poloznikov AA, Khristichenko AY, Smirnova NA, Hushpulian DM, Gaisina IN, Osipyants Al, et al. Structural optimization of adaptaquin, a HIF prolyl hydroxylase inhibitor. Russ Chem Bull. 2019; 68 (1):168-73. DOI: 10.1007/s11172-019-2433-3.

10. Knyazev EN, Zakharova GS, Astakhova LA, Tsypina IM, Tonevitsky AG, Sukhikh GT. Metabolic Reprogramming of Trophoblast Cells in Response to Hypoxia. Bull Exp Biol Med. 2019; 166 (3): 321-5. DOI: 10.1007/s10517-019-04342-1.

11. Shkurnikov MY, Makarova YA, Knyazev EN, Fomicheva KA Nyushko KM, Saribekyan EK, et al. Profile of microRNA in Blood Plasma of Healthy Humans. Bull Exp Biol Med. 2016; 160 (5): 632-4. DOI: 10.1007/s10517-016-3235-3.

12. Love MI, Huber W, Anders S. Moderated estimation of fold change and dispersion for RNA-seq data with DESeq2. Genome Biol. 2014; 15 (12): 550. DOl: 10.1186/s13059-014-0550-8.

13. Yang W, Rosenstiel $P$, Schulenburg $H$. aFold - using polynomial uncertainty modelling for differential gene expression estimation from RNA sequencing data. BMC Genomics. 2019; 20 (1): 364. DOI: 10.1186/s12864-019-5686-1.

14. Benita $Y$, Kikuchi $H$, Smith $A D$, Zhang MQ, Chung DC, Xavier RJ. An integrative genomics approach identifies Hypoxia Inducible Factor-1 (HIF-1)-target genes that form the core response to hypoxia. Nucleic Acids Res. 2009; 37 (14): 4587-602. DOl: 10.1093/nar/gkp425

15. Xia N, Tan W-F, Peng Q-Z, Cai H-N. MiR-374b reduces cell proliferation and cell invasion of cervical cancer through regulating FOXM1. Eur Rev Med Pharmacol Sci. 2019; 23 (2): 513-21. DOI: 10.26355/eurrev_201901_16863.

16. Zhou F, Sun $Y$, Gao $Q$, Wang $H$. microRNA-21 regulates the proliferation of placental cells via FOXM1 in preeclampsia. Exp Ther Med. 2020; 20 (3): 1871-8. DOI: 10.3892/etm.2020.8930.

17. Baumann MU, Zamudio S, Illsley NP. Hypoxic upregulation of glucose transporters in BeWo choriocarcinoma cells is mediated by hypoxia-inducible factor-1. Am J Physiol Cell Physiol. 2007; 293 (1): C477-85. DOI: 10.1152/ajpcell.00075.2007.

18. Francois LN, Gorczyca L, Du J, Bircsak KM, Yen E, Wen X, et al. Down-regulation of the placental BCRP/ABCG2 transporter in response to hypoxia signaling. Placenta. 2017; 51: 57-63. DOI: 10.1016/j.placenta.2017.01.125.

19. Hayashi M, Sakata M, Takeda T, Yamamoto T, Okamoto $Y$, Sawada K, et al. Induction of glucose transporter 1 expression through hypoxia-inducible factor 1 alpha under hypoxic conditions in trophoblast-derived cells. J Endocrinol. 2004; 183 (1): 145-54. DOI: 10.1677/joe.1.05599.

20. Fukasawa M, Tsuchiya T, Takayama E, Shinomiya N, Uyeda K, Sakakibara R, et al. Identification and characterization of the hypoxia-responsive element of the human placental 6-phosphofructo-2-kinase/fructose-2,6-bisphosphatase gene. J Biochem. 2004; 136 (3): 273-7. DOI: 10.1093/jb/mvh137.

21. Gleadle JM, Ebert BL, Firth JD, Ratcliffe PJ. Regulation of angiogenic growth factor expression by hypoxia, transition metals, and chelating agents. Am J Physiol. 1995; 268 (6 Pt 1): C1362-8. DOI: 10.1152/ajpcell.1995.268.6.C1362.

22. Hoffmeister T, Schwenke D, Wachsmuth $N$, Krug O, Thevis M, Byrnes WC, et al. Erythropoietic effects of low-dose cobalt application. 
Drug Test Anal. 2019; 11 (2): 200-7. DOI: 10.1002/dta.2478.

23. Befani C, Mylonis I, Gkotinakou I-M, Georgoulias P, Hu C-J, Simos G, et al. Cobalt stimulates HIF-1-dependent but inhibits HIF-2-dependent gene expression in liver cancer cells. Int $J$ Biochem Cell Biol. 2013; 45 (11): 2359-68. DOI: 10.1016/j. biocel.2013.07.025.

24. Youssef HMG, Marei ES. Association of MicroRNA-210 and MicroRNA-155 with severity of preeclampsia. Pregnancy Hypertens. 2019; 17: 49-53. DOI: 10.1016/j.preghy.2019.05.010.

25. Bian H, Zhou Y, Zhou D, Zhang Y, Shang D, Qi J. The latest progress on miR-374 and its functional implications in physiological and pathological processes. J Cell Mol Med. 2019; 23 (5): 3063-76. DOI: $10.1111 / \mathrm{jcmm} .14219$.

26. Cook J, Bennett PR, Kim SH, Teoh TG, Sykes L, Kindinger LM, et al. First Trimester Circulating MicroRNA Biomarkers Predictive of
Subsequent Preterm Delivery and Cervical Shortening. Sci Rep. 2019; 9 (1): 5861. DOl: 10.1038/s41598-019-42166-1.

27. Kim SH, Maclntyre DA, Binkhamis R, Cook J, Sykes L, Bennett PR, et al. Maternal plasma miRNAs as potential biomarkers for detecting risk of small-for-gestational-age births. EBioMedicine. 2020; 62: 103145. DOI: 10.1016/j.ebiom.2020.103145.

28. Illsley NP, Caniggia I, Zamudio S. Placental metabolic reprogramming: do changes in the mix of energy-generating substrates modulate fetal growth? Int J Dev Biol. 2010; 54 (2-3): 409-19. DOI: 10.1387/ijdb.082798ni.

29. Monteiro LJ, Cubillos S, Sanchez M, Acuña-Gallardo S, Venegas P, Herrera V, et al. Reduced FOXM1 Expression Limits Trophoblast Migration and Angiogenesis and Is Associated With Preeclampsia. Reprod Sci. 2019; 26 (5): 580-90. DOI: $10.1177 / 1933719118778798$

\section{Литература}

1. Yang $\mathrm{C}$, Song G, Lim W. Effects of extracellular vesicles on placentation and pregnancy disorders. Reproduction. 2019; 158 (5): R189-96. DOI: 10.1530/REP-19-0147.

2. Li H, Ouyang Y, Sadovsky E, Parks WT, Chu T, Sadovsky Y, Unique microRNA Signals in Plasma Exosomes from Pregnancies Complicated by Preeclampsia. Hypertension. 2020; 75 (3): $762-$ 71. DOI: 10.1161/HYPERTENSIONAHA.119.14081.

3. Makarova J, Turchinovich A, Shkurnikov M, Tonevitsky A. Extracellular miRNAs and Cell-Cell Communication: Problems and Prospects. Trends Biochem Sci. 2021. DOI: 10.1016/j.tibs.2021.01.007.

4. Makarova JA, Maltseva DV, Galatenko W, Abbasi A, Maximenko DG, Grigoriev Al, et al. Exercise immunology meets MiRNAs. Exerc Immunol Rev. 2014; 20: 135-64.

5. Nikulin SV, Knyazev EN, Gerasimenko TN, Shilin SA, Gazizov IN, Zakharova GS, et al. Impedance Spectroscopy and Transcriptome Analysis of Choriocarcinoma BeWo b30 as a Model of Human Placenta. Mol Biol. 2019; 53 (3): 411-8. DOI: 10.1134/ S0026893319030130.

6. Nikulin SV, Knyazev EN, Gerasimenko TN, Shilin SA, Gazizov IN, Zakharova GS, et al. Non-Invasive Evaluation of Extracellular Matrix Formation in the Intestinal Epithelium. Bull Exp Biol Med. 2018; 166 (1): 35-8. DOI: 10.1007/s10517-018-4283-7.

7. Samatov TR, Shkurnikov MU, Tonevitskaya SA, Tonevitsky AG. Modelling the metastatic cascade by in vitro microfluidic platforms. Prog Histochem Cytochem. 2015; 49 (4): 21-9. DOI: 10.1016/j. proghi.2015.01.001.

8. Muñoz-Sánchez J, Chánez-Cárdenas ME. The use of cobalt chloride as a chemical hypoxia model. J Appl Toxicol. 2019; 39 (4): 556-70. DOI: 10.1002/jat.3749.

9. Poloznikov AA, Khristichenko AY, Smirnova NA, Hushpulian DM, Gaisina IN, Osipyants Al, et al. Structural optimization of adaptaquin, a HIF prolyl hydroxylase inhibitor. Russ Chem Bull. 2019; 68 (1):168-73. DOI: 10.1007/s11172-019-2433-3.

10. Knyazev EN, Zakharova GS, Astakhova LA, Tsypina IM, Tonevitsky AG, Sukhikh GT. Metabolic Reprogramming of Trophoblast Cells in Response to Hypoxia. Bull Exp Biol Med. 2019; 166 (3): 321-5. DOI: 10.1007/s10517-019-04342-1

11. Shkurnikov MY, Makarova YA, Knyazev EN, Fomicheva KA, Nyushko KM, Saribekyan EK, et al. Profile of microRNA in Blood Plasma of Healthy Humans. Bull Exp Biol Med. 2016; 160 (5): 632-4. DOI: 10.1007/s10517-016-3235-3.

12. Love Ml, Huber W, Anders S. Moderated estimation of fold change and dispersion for RNA-seq data with DESeq2. Genome Biol. 2014; 15 (12): 550. DOI: 10.1186/s13059-014-0550-8.

13. Yang $\mathrm{W}$, Rosenstiel $\mathrm{P}$, Schulenburg $\mathrm{H}$. aFold - using polynomial uncertainty modelling for differential gene expression estimation from RNA sequencing data. BMC Genomics. 2019; 20 (1): 364. DOI: 10.1186/s12864-019-5686-1.

14. Benita Y, Kikuchi H, Smith AD, Zhang MQ, Chung DC, Xavier RJ. An integrative genomics approach identifies Hypoxia Inducible Factor-1 (HIF-1)-target genes that form the core response to hypoxia. Nucleic Acids Res. 2009; 37 (14): 4587-602. DOl: 10.1093/nar/gkp425.
15. Xia N, Tan W-F, Peng Q-Z, Cai H-N. MiR-374b reduces cell proliferation and cell invasion of cervical cancer through regulating FOXM1. Eur Rev Med Pharmacol Sci. 2019; 23 (2): 513-21. DOI: 10.26355/eurrev_201901_16863.

16. Zhou F, Sun $Y$, Gao Q, Wang H. microRNA-21 regulates the proliferation of placental cells via FOXM1 in preeclampsia. Exp Ther Med. 2020; 20 (3): 1871-8. DOI: 10.3892/etm.2020.8930.

17. Baumann MU, Zamudio S, Illsley NP. Hypoxic upregulation of glucose transporters in BeWo choriocarcinoma cells is mediated by hypoxia-inducible factor-1. Am J Physiol Cell Physiol. 2007; 293 (1): C477-85. DOI: 10.1152/ajpcell.00075.2007.

18. Francois LN, Gorczyca L, Du J, Bircsak KM, Yen E, Wen X, et al. Down-regulation of the placental BCRP/ABCG2 transporter in response to hypoxia signaling. Placenta. 2017; 51: 57-63. DOl: 10.1016/j.placenta.2017.01.125.

19. Hayashi M, Sakata M, Takeda T, Yamamoto T, Okamoto $Y$, Sawada K, et al. Induction of glucose transporter 1 expression through hypoxia-inducible factor 1 alpha under hypoxic conditions in trophoblast-derived cells. J Endocrinol. 2004; 183 (1): 145-54. DOI: 10.1677/joe.1.05599.

20. Fukasawa M, Tsuchiya T, Takayama E, Shinomiya N, Uyeda K, Sakakibara R, et al. Identification and characterization of the hypoxia-responsive element of the human placental 6-phosphofructo-2-kinase/fructose-2,6-bisphosphatase gene. J Biochem. 2004; 136 (3): 273-7. DOI: 10.1093/jb/mvh137.

21. Gleadle JM, Ebert BL, Firth JD, Ratcliffe PJ. Regulation of angiogenic growth factor expression by hypoxia, transition metals, and chelating agents. Am J Physiol. 1995; 268 (6 Pt 1): C1362-8. DOI: 10.1152/ajpcell.1995.268.6.C1362.

22. Hoffmeister T, Schwenke D, Wachsmuth N, Krug O, Thevis M, Byrnes WC, et al. Erythropoietic effects of low-dose cobalt application. Drug Test Anal. 2019; 11 (2): 200-7. DOl: 10.1002/dta.2478.

23. Befani C, Mylonis I, Gkotinakou I-M, Georgoulias P, Hu C-J, Simos G, et al. Cobalt stimulates HIF-1-dependent but inhibits HIF-2-dependent gene expression in liver cancer cells. Int $J$ Biochem Cell Biol. 2013; 45 (11): 2359-68. DOI: 10.1016/j. biocel.2013.07.025

24. Youssef HMG, Marei ES. Association of MicroRNA-210 and MicroRNA-155 with severity of preeclampsia. Pregnancy Hypertens. 2019; 17: 49-53. DOI: 10.1016/j.preghy.2019.05.010.

25. Bian H, Zhou Y, Zhou D, Zhang Y, Shang D, Qi J. The latest progress on miR-374 and its functional implications in physiological and pathological processes. J Cell Mol Med. 2019; 23 (5): 3063-76. DOI: $10.1111 / \mathrm{jcmm} .14219$.

26. Cook J, Bennett PR, Kim SH, Teoh TG, Sykes L, Kindinger LM, et al. First Trimester Circulating MicroRNA Biomarkers Predictive of Subsequent Preterm Delivery and Cervical Shortening. Sci Rep. 2019: 9 (1): 5861. DOI: 10.1038/s41598-019-42166-1.

27. Kim SH, Maclntyre DA, Binkhamis R, Cook J, Sykes L, Bennett PR, et al. Maternal plasma miRNAs as potential biomarkers for detecting risk of small-for-gestational-age births. EBioMedicine. 2020; 62: 103145. DOI: 10.1016/i.ebiom.2020.103145.

28. Illsley NP, Caniggia I, Zamudio S. Placental metabolic 
reprogramming: do changes in the mix of energy-generating substrates modulate fetal growth? Int J Dev Biol. 2010; 54 (2-3): 409-19. DOI: 10.1387/ijdb.082798ni.

29. Monteiro LJ, Cubillos S, Sanchez M, Acuña-Gallardo S,
Venegas P, Herrera V, et al. Reduced FOXM1 Expression Limits Trophoblast Migration and Angiogenesis and Is Associated With Preeclampsia. Reprod Sci. 2019; 26 (5): 580-90. DOI: 10.1177/1933719118778798. 